\title{
Beylikdüzü İlçesi Yeşil Alan Sisteminin Mevcut Durumunun Değerlendirilmesi
}

\author{
Zeynep KÖMÜR ARDALI ${ }^{1}$, Elif Ebru Şİ̧SMAN ${ }^{2 *}$ \\ ${ }^{1}$ Yüksek Lisans Öğrencisi Tekirdağ Namık Kemal Üniversitesi Güzel Sanatlar Tasarım ve Mimarlık Fakültesi \\ Peyzaj Mimarlığı Anabilim Dalı, ORCID:0000-0003-1402-783X \\ ${ }^{2}$ Tekirdağ Namık Kemal Üniversitesi Güzel Sanatlar Tasarım ve Mimarlık Fakültesi Peyzaj Mimarlığı Bölümü, \\ Tekirdağ, Türkiye, ORCID: 0000-0002-5114-7980
}

\section{Öz}

Kentsel yeşil alanlar sahip oldukları estetik ve işlevsel özellikleri ile sürdürülebilir kentler için önem taşımaktadır. $\mathrm{Bu}$ alanların kent insanına hizmet edebilmesi; konumu, büyüklügü ve ulaşılabilirlikleri gibi özellikleri ile yakından ilgilidir. Kentlerin kişi başına sahip oldukları yeşil alan miktarı medeniyetin göstergesi olarak kabul edilmektedir. Kentsel yeşil alanlar aktif ve pasif yeşil alanlar olmak üzere iki gruba ayrılmaktadır. Bu çalışmada; İstanbul ili Beylikdüzü ilçesi örneğinde, kentsel yeşil alanların mevcut durumu araştırılmış ve ilçede kişi başına düşen aktif yeşil alan miktarı hesaplanmıştır. Bulunan değer 3194 Sayılı İmar Kanunu'nun Plan Yapımına Ait Esaslara Dair Yönetmeliğinde belirtilen $10 \mathrm{~m}^{2}$ standardı ile karşılaştırılmıştır. Ayrıca, İmar planında planlanan aktif yeşil alan miktarı ile mevcutta bulunan aktif yeşil miktarı karşılaştırılmıştır. İlgili yönetmelikte yeşil alan miktarı; çocuk oyun alanları, mahalle ve semt parkları, kent parkları ve spor alanlarının toplamı için geçerlidir. İlçede çocuk oyun alanları mahalle parkları içerisinde yer aldığı için bir bütün olarak hesaplanmıştır. Bu bağlamda İlçede İmar planına göre hedeflenen park alanı; \%26 oranında gerçekleştirilmiş ve kişi başına düşen aktif yeşil alan miktarı ise $3,41 \mathrm{~m}^{2}$ olarak bulunmuştur. Bu değer yönetmelikte belirtilen $10 \mathrm{~m}^{2}$ standardının altında kalmıştır.

Anahtar Kelimeler: Kent, aktif yeşil alan, yeşil alan standartı, kişi başı yeşil alan miktarı, Beylikdüzü

\section{Evaluation of Present Status of Green Area System in The Beylikdüzü District}

\begin{abstract}
Urban green spaces are important for sustainable cities with their aesthetic and functional features. Green areas can serve the urban people; It is closely related to features such as location, size and accessibility. The amount of green space that cities have per capita is accepted as an indicator of civilization. Urban green areas are divided into two groups as active and passive green areas. In this study; a case of Beylikdüzü district of Istanbul province, the current situation of urban green areas was investigated and the amount of active green areas per capita in the district was calculated. The value found was compared with the $10 \mathrm{~m}^{2}$ standard specified in the Regulation on the Principles of Planning of the Zoning Law No. 3194. In addition, the amount of active green space planned in the zoning plan and the amount of active green space available were compared. The amount of green space in the relevant regulation; It is valid for the sum of children's playgrounds, neighborhood and district parks, city parks and sports fields. Since children's playgrounds are located in neighborhood parks in the district, they are calculated as a whole. In this context, the park area targeted according to the Development Plan in the District; It was realized at the rate of $26 \%$ and the amount of active green area per capita was found as $3.41 \mathrm{~m}^{2}$. This value remained below the $10 \mathrm{~m}^{2}$ standard specified in the regulation.
\end{abstract}

Keywords: Urban, active green space, green space standard, amount of green space per person, Beylikdüzü

\footnotetext{
*Sorumlu Yazar (Corresponding Author): 


\section{Giriş}

İnsanlar, varoluşlarından bu yana doğa ile iç içe yaşamışlardır. Avcı göçebe bir yaşam süren insanoğlu, toprağı kullanıp hayvanları evcilleştirerek ürün almaya, tarımsal faaliyette bulunmaya başlamıştır. Topraklarını işleyerek geçinen aileler; birlikte yaşayarak tehlikelere karşı daha güçlü olmak, daha az emek daha çok iş yapmak ve birbirlerinin eksikliklerini tamamlamak için bir araya gelerek bir toplum oluşturmuşlardır. Arseven'e göre “ toplum evi” denilen kentler işte bu aşamada ortaya çıkmıştır (Erdem, 1995; Albayrak 2006). Dinamik bir yapıya sahip olan kentler, sürekli bir değişim geçirmektedirler. Nüfus artışı sonucunda kentler büyümekte ve bu büyüme kentin fiziksel dokusunu etkilemektedir (Aydemir, 1999; Eren, 2012). Kentlerin fiziksel dokusundaki değişim süreci kentleşme kavramını gündeme getirmektedir (Sağlam, 2006). Keleş (1990)'e göre, kentleşme; sanayi ve ekonomik büyümeyle kentlerin artması, toplumsal ilişkilerinde kentlere özgü değişikliklere yol açan, bir nüfus birikimi sürecidir (Albayrak, 2006). Hızlı kentleşme kentlerin ekolojik yapılarını da etkilemektedir. Çevre politikalarının yetersizliği, aşırı yapılaşma, sosyal ve ekonomik problemler arazilerin yasal olmayan işgaline, dolayısıyla yeşil alanların kaybolmasına neden olmaktadır (Melchert, 2005). Hızla büyüyen kentler, betonlaşma nedeni ile insanlar üzerinde bir baskı yaratmaktadır. Bu baskı, insanların psikolojik açıdan rahatlama, sosyal ve kültürel aktivitelerde bulunma ihtiyaçlarını arttırmaktadır. Bu ihtiyacın en kolay yoldan sağlanması insanlara yaşadığı ortamda çeşitli sosyal ve kültürel faaliyetler yüklenmiş açık - yeşil alanlar oluşturmakla mümkündür. Pamay (1978)'a göre; açık ve yeşil alanlar, kent içi ve kırsal karakterdeki yerleşmelerde, insanların çeşitli rekreatif ihtiyaçları için yararlandıkları küçük-büyük yüzeyler ve boşluklardır (Budak. 2010). Açık yeşil alanlar genel anlamda kent içerisindeki dağılımı açısından; dağınık ve yeşil bantlar sistemi olarak (Yıldızc1, 1987), rekreasyonel aktivite türüne göre aktif ve pasif yeşil alanlar, kullanım veya mülkiyet durumuna göre ise; kamusal, yarı-özel ve özel olarak da sınıflandırılabilmektedir (Önder, 1997; Klompmaker, et.al. 2018) .

Açık - yeşil alanların kentlerde estetik ve fonksiyonel kullanımlarının yanı sıra, kente ekonomik, ekolojik, fiziksel, rekreasyonel ve psikolojik açıdan olumlu etkileri vardır (Chiesura, 2004; Garcia, 2017; Daniels et.al., 2018). Özellikle kent insanı için aktif ve pasif rekreasyon imkanı sağlayan, doğa ile bütünleşme olanağı sunan ve kent iklimine katkı sağlayan bu alanlar kentlerin yaşam kalitesini arttırmaktadır (Gül ve Küçük, 2001; Aksoy, 2001; Gül vd., 2020). Bu alanların bir sistem dahilinde kentsel, bölgesel ve ülkesel ölçekte bütüncül olarak ele alınması ve ilişkilendirilmesi son dönemlerde önem kazanmaya başlamıştır. Geniş park ağları, kent yaşam kalitesini olumlu etkilediği gibi (Larson et.al., 2016), insan sağlığ üzerinde de olumlu etkilere sahiptir (Zhang et.al., 2015). Kentler fiziki çevre ve doğayla uyumlu, insanlar için sosyal ve ekonomik anlamda güvenli olacak şekilde planlanmalıdır. Planlama anlayışı; doğadan maksimum verim alma ve doğaya zarar vermeme olmalıdır (Değerliyurt, 2014). Ancak hızla kentleşen bir sistemde sağlıklı ekolojik dengelerden de söz etmek oldukça güçtür. Yetersiz çevre politikaları, sosyal ve ekonomik problemler sürdürülebilir olmayan yapılaşmaya, arazinin yasal olmayan işgaline ve çevre koruma çalışmalarının aksamasına dolayısıyla yeşil alanların kaybına da neden olmaktadır (Melchert, 2005).

Dil (2004)'e göre; Yeşil alanların planlamasında, yürüme uzaklığı temel alınmaktadır. Yeşil alanlara ulaşılabilirlik arttıkça, kullanım yoğunluğu da artmaktadır. Avrupa Komisyonu Kentsel Denetim raporunda kentsel yeşil alanlara ideal yürüme süresi 15 dakika olarak verilmektedir (European Communities, 2000). Yapılan çalışmalarda yeşil alanların çeşitlerine göre en uygun ulaşım ve yürüme mesafeleri; çocuk bahçeleri-oyun alanları için 400 m yürüme süresi 10 dakika, semt-mahalle parkları için 800 m, yürüme süresi 20 dakika, kent parkları için ise 1200m yürüme süresi 30 dakika olmalıdır (Altunkasa, 2004; Polat ve Önder, 2012).

İşlevselliği açısından kente birçok olumlu etkileri olan açık-yeşil alanların niceliksel olarak da yeterlilik göstermesi gerekmektedir. Açık-yeşil alanların konumu, büyüklüğü, ulaş1labilirlikleri gibi toplumun bu alanlardan faydalanma kolaylığı sağlayacak olan yeterlilik düzeyi ise son derece önemlidir. Pamay (1978)'e göre; Türkiye'de, parklar; mahalle park1 8 dekar, semt park1 50 dekar, kent parkı 400 dekar minimum alan büyüklüğüne sahip olmalıdır (Albayrak, 2006). Kent oluşumunda kaybedilen doğanın, kent insanına belirlenen standartlarda tekrar geriye kazandırılması ve kentte hızla artan nüfusa paralel olarak açık-yeşil alanlarında hızla planlanıp uygulanması, modern ve sağlıklı bir kent düzeni için büyük önem teşkil etmektedir. Ancak kontrollü bir büyümenin sağlanamadığı günümüz kentlerinde ise her geçen gün kişi başına düşen açık-yeşil alan miktarı azalmaktadır (Çetiner, 1990; Aksoy, 2004; Ceylan, 2007).

Fiziksel planlama kapsamında değerlendirilen açık yeşil alanlar, Türkiye'de, 3194 sayılı İmar Kanunu ve buna bağlı olarak çıkarılan yönetmelikler kapsamında planlanmaktadır. Bu bağlamda yürürlükte olan yasal açık ve yeşil alanlara yönelik standartlar, 3194 sayılı İmar Yasası'nın 'İmar Planı Yapılması ve değişikliklerine Ait Esaslara Dair Yönetmeliğinde' aktif yeşil alan standardı belediye ve mücavir alan sınırı içerisinde $7 \mathrm{~m}^{2} / \mathrm{kişi}, \mathrm{bu}$ sınırlar dışarısında ise $14 \mathrm{~m}^{2}$ /kişi olarak öngörülmüştür. Ancak 3194 sayılı imar kanununda belirtilen kentsel yeşil alanlar için kişi başına $7 \mathrm{~m}^{2}$ yeşil alan standardı 02.09.1999 tarihli resmi gazetede yayınlanan 'İmar Planı 
Değişikliğine' göre $10 \mathrm{~m}^{2}$ 'ye çıkartılmıştır (Çinçinoğlu, 2001). Yine İmar Kanunu ile ilişkili olarak çıkarılan Mekansal Planlar Yapım Yönetmeliği, Ek 2 de verilen açık ve yeşil alan miktarı ilçe sınırları dahilinde kişi başına $10 \mathrm{~m}^{2}$, il bütününde ise kişi başına $5 \mathrm{~m}^{2}$ ilave edilmek üzere açık yeşil alan standardı $15 \mathrm{~m}^{2}$ olarak belirlenmiştir (Anonim, 2014).

Çalışma kapsamında; İstanbul'un Beylikdüzü ilçe sınırları içerisindeki mevcut aktif yeşil alanlar belirlenmiştir. $\mathrm{Bu}$ yeşil alanların tamamı, mülkiyeti devlete ait kamu arazilerinden oluşmaktadır. İlçede kişi başına düşen aktif yeşil alan miktarı hesaplanarak, aktif yeşil alanların yeterlilik durumu değerlendirilmiştir. Yerinde incelenen alanların durumları ve işlevselliği plan notları halinde ele alınıp alanlar niteliksel olarak da değerlendirilmişstir. Tüm değerlendirmeler sonucunda Beylikdüzü ilçesi aktif yeşil alanların niteliksel ve niceliksel eksikliklerine yönelik çözüm önerileri getirilmiştir.

\section{Materyal ve Metot}

\subsection{Materyal}

Araştırma materyalini, Beylikdüzü ilçe sınırları içerisindeki mevcut aktif yeşil alanlar oluşturmaktadır. Yaklaşık $37,38 \mathrm{~km}^{2}$ alana sahip olan ilçe, İstanbul ilinin 39 ilçesinden biridir. Güneyde Marmara Denizine, Doğuda Avcılar, kuzeyde Esenyurt, batıda ise Büyükçekmece ilçelerine komşudur. Beylikdüzü ilçesi; Adnan Kahveci, Barış, Büyükşehir, Cumhuriyet, Dereağzı, Gürpınar, Kavakl1, Marmara, Sahil ve Yakuplu olmak üzere 10 adet mahalleden oluşmaktadır (Anonim, 2017a) (Şekil 1). Türkiye İstatistik Kurumu’nun (TUİK) 2016 verilerine göre ilçe nüfusu 297,420 kişidir (Anonim, 2017b).

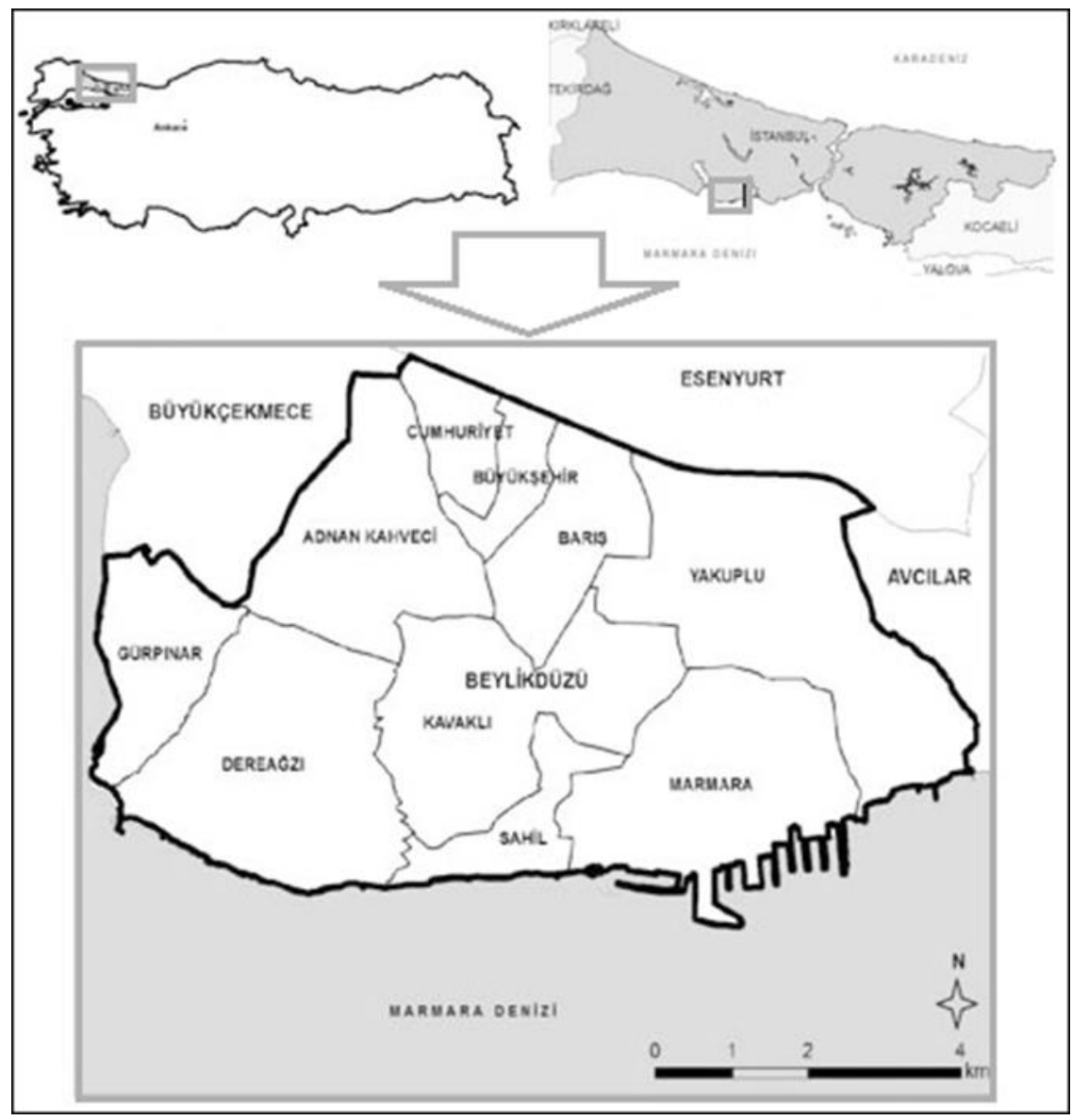

Şekil 1. Beylikdüzü ilçesinin konumu (Anonim 2017 c)

Beylikdüzü ilçesi geniş düzlüklere sahip, yüksek oranda Akdeniz iklimi etkisi altında kalan maki, çalı ve ot vejetasyonun hakim olduğu tarıma elverişli arazilerden oluşmaktadır. Tarihte Bizans döneminde safiye evlerinden oluşan Yunanlıların bağcılık yaptığı, Osmanlı paşalarının avcılık yapıp geniş çiftlik arazilerinin bulunduğu bir bölge iken, Cumhuriyet dönemiyle birlikte tarımsal faaliyetlerin yapıldığı bir bölge olmuştur. Cumhuriyet dönemi ile birlikte başlayan tarımsal faaliyetler 60'l1 yıllarda Enver Adakan'nın bölgeye diktirmiş olduğu 450000 orman 
fỉdanıyla daha da zenginleşmiş ve tarım bu dönemde zirve noktasına ulaşmıştır. Büyük bir oranda tarım arazilerine ev sahipliği yapan alanda, 80'li yıllarda şehirleşme ile birlikte tarım arazileri yerini yapılaşmalara bırakmıştır. 2000'li yıllarda ise düzenli yapılaşmanın getirmiş olduğu planlı arazi kullanımlarıyla ilçeye fonksiyonlu, estetik geniş açık yeşil alanlar kazandırılmıştır (Anonim, 2017d). Şekil 2' de ilçenin yıllara göre şehirleşme süreci görülmektedir.

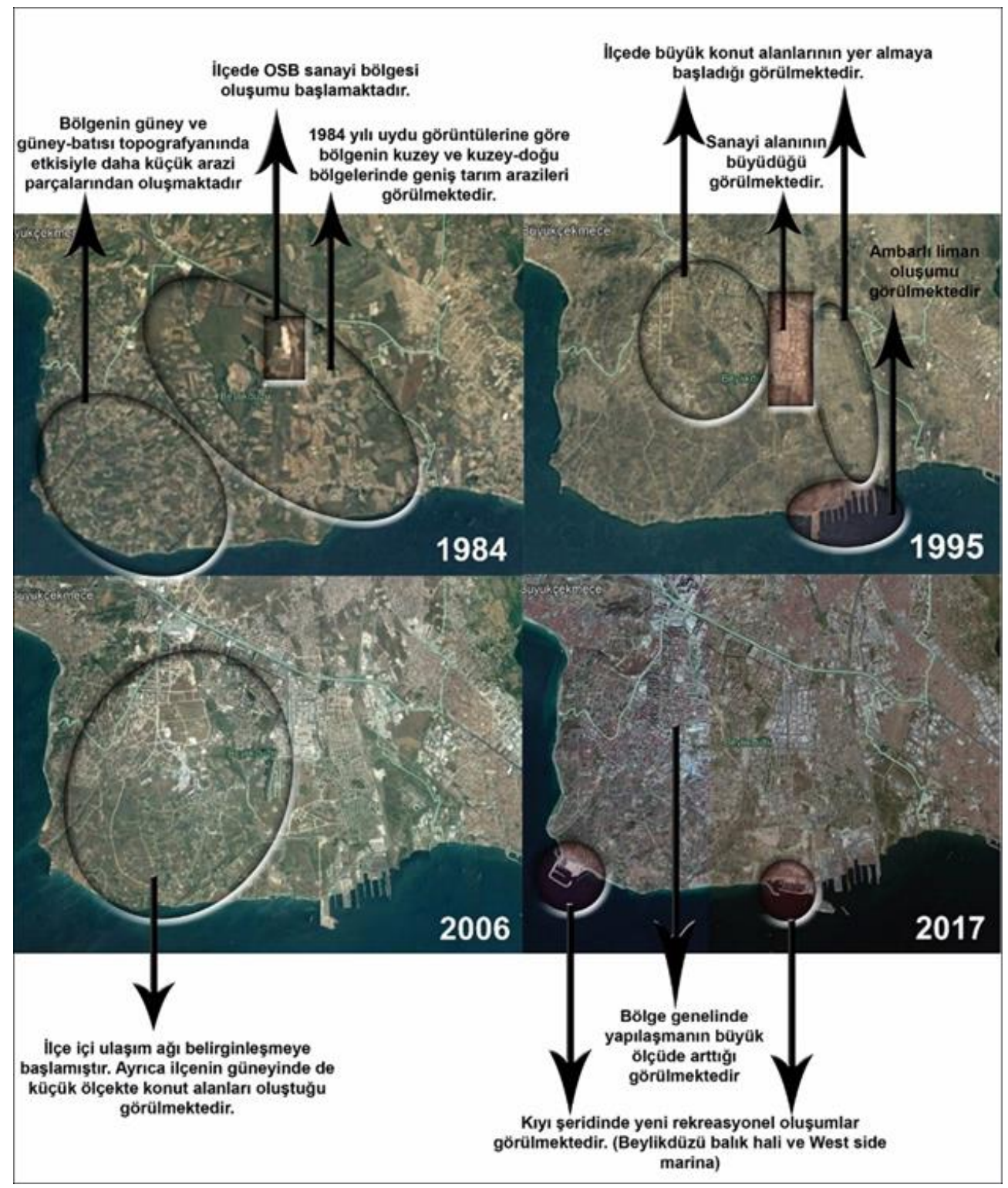

\subsection{Metot}

Şekil 2. Beylikdüzü ilçesinin yıllara göre şehirleşme süreci

Araştırmanın ilk aşamasında öncelikli olarak araştırma alanın sınırları belirlenmiştir. Daha sonra konuya ilişkin literatür çalışması yapılmış ve araştırma alanına ilişkin mevcut veriler elde edilmiştir. Bu kapsamda; Beylikdüzü Belediyesi Plan Proje Müdürlügü̈nden Beylikdüzü ilçesine ait imar planları temin edilmiştir. Kentsel alan kullanımlarının belirlenmesinde 1/1000 ölçekli Beylikdüzü ilçesi İmar Planı paftalarından yararlanılmıştır. Araştırma alanına ilişkin sosyal yapının analizinde TÜİK verileri, doğal ve kültürel özellikler Beylikdüzü Kent Bilgi Sisteminden, demografik yapı Beylikdüzü Nüfus Müdürlüğünden talep edilerek mahalle bazında nüfus bilgilerine ulaşılmıştır. İlçedeki yeşil alanlara ilişsin veriler Beylikdüzü Park Bahçeler Müdürlüğü’nden temin edilmiştir. Bu aşamada yazınsal, sayısal ve görsel veriler elde edilmiştir. İkinci aşamada elde edilen veriler doğrultusunda çalışma alanın mevcut durumunun belirlenmesi için arazi çalışmaları yapılmıştır. İmar planı altlık olacak şekilde mülkiyeti kamuya ait olan aktif yeşil alanlar yerinde tespit edilmiştir. Alanların fotoğrafları çekilip, mevcut durumları not alınmıştır. Sahada tespiti yapılan açık-yeşil alanlar 1/1000 ve 1/5000 ölçekli Beylikdüzü ilçesi imar paftası üzerine bilgisayar ortamında işlenmiştir. Kişi başına düşen aktif yeşil alan miktarının 
hesaplanabilmesi için ilçedeki çocuk oyun alanları, mahalle parkları, kent parkları ile spor alanları mahalle bazında listelenmiş ve ölçülendirilmiştir. Çocuk oyun alanları mahalle parkları içerisinde yer aldığı için mahalle parkları ile çocuk oyun alanları birlikte hesaplanmıştır. Nüfus bilgileri doğrultusunda mahalle bazında kişi başına düşen mahalle parkları (çocuk oyun alanları dahil) ile spor alanları hesaplanmıştır. Kent parkı ise ilçe bazında hesaplanmıştır. Son aşamada ise, ortaya çıkan sonuçlar dikkate alınarak, sorunlar belirtilmiş buna ilişkin çözüm önerileri getirilmiştir.

\section{Bulgular}

Beylikdüzü ilçe sınırları içerisindeki mevcut açık - yeşil alanlar, mahalle parkları ve çocuk oyun alanları, kent parkları ve spor alanları başlıklarında ele alınmış, mevcut tüm parklar nicelik bakımından Mekansal Planlar Yönetmeliğindeki kişi başına düşmesi gereken $10 \mathrm{~m}^{2}$ standardına göre değerlendirilmiştir. Mevcut parkların konumları ve ulaşılabilirlik analizleri yapılarak parkların ilçe içesindeki dağılımları irdelenmiştir. Ayrıca ilçedeki açık-yeşil alanlar; parkların yenilik durumları, park içerisindeki yeşil alan miktarı, donatı elemanları ve spor alanlarının sert zemin durumları şeklinde analizler yapılarak ilçeye ait park alanları niteliksel olarak da incelenmiştir. Bu kapsamda;

Beylikdüzü ilçesi mahalle parkları ve çocuk oyun alanları; Beylikdüzü ilçesinde çocuk oyun alanlarına, site içlerinde, mahalle parklarında, kent parkında ve sahil şeridi yeşil alan içerisinde rastlanılmaktadır. 10 adet mahalleden oluşan Beylikdüzü'nde çocuk oyun alanları, nüfusun fazla ve sitelerin yoğun olduğu bölgelerde sayıca fazladır. İlçede çocuk oyun alanları mahalle parkları içerisinde yer aldığı için mahalle parklarıyla birlikte değerlendirilmiştir. Anonim (2017e) verilerine göre; ilçede toplam 125 adet çocuk oyun alanı olan park bulunmaktadır (Tablo 1) (Şekil 3). Bu parkların 123 tanesi mahalle parkı olup 2 tanesi ise kent parkı niteliği taşımaktadır. İlçedeki çocuk oyun alanları dahil mahalle parklarının toplam alanı $536.432 \mathrm{~m}^{2}$ dir. İlçede kişi başına düşen mahalle park alanı miktarı ise $1.80 \mathrm{~m}^{2}$ dir. Beylikdüzü mahalleleri arasında, kişi başına düşen mahalle parkı/çocuk oyun alanı, en düşük Kavaklı mahallesinde iken en yüksek Sahil mahallesindedir.

Tablo 1. Beylikdüzü ilçesi mahalle parklarının kişi başına düşen alan miktarı

\begin{tabular}{|c|c|c|c|c|}
\hline \multirow[t]{2}{*}{ Mahalle } & \multirow[t]{2}{*}{ Nüfus (kişi) } & \multirow[t]{2}{*}{ Mahalle parkı $\left(\mathrm{m}^{2}\right)$} & Kişi başina düşen & \multirow{2}{*}{$\begin{array}{l}\text { Türkiye } \\
\text { standardı } \\
\left(\mathbf{m}^{2}\right)\end{array}$} \\
\hline & & & $\begin{array}{l}\text { mahalle parkı } \\
\left(\mathbf{m}^{2}\right)\end{array}$ & \\
\hline Adnan Kahveci & 80.681 & 118.587 & 1.47 & \multirow{11}{*}{3.5} \\
\hline Barış & 51.476 & 87.835 & 1.71 & \\
\hline Büyükşehir & 20.851 & 60.447 & 2.90 & \\
\hline Cumhuriyet & 20.837 & 55.870 & 2.68 & \\
\hline Dereağzi & 10.401 & 28.001 & 2.69 & \\
\hline Gürpınar & 18.936 & 38.507 & 2.03 & \\
\hline Kavaklı & 23.596 & 11.576 & 0.49 & \\
\hline Marmara & 25.609 & 74.896 & 2.93 & \\
\hline Sahil & 4.234 & 30.405 & 7.18 & \\
\hline Yakuplu & 40.792 & 30.308 & 0.74 & \\
\hline TOPLAM & 297.420 & 536.432 & 1.80 & \\
\hline
\end{tabular}

: En düşük değer

:En yüksek değer

Beylikdüzü ilçesi kent parkları; Beylikdüzü ilçesinde kent parkı niteliğinde 2 adet park bulunmaktadır. Bunlardan birincisi Kavaklı deresinin oluşturmuş olduğu vadinin kuzey bölümündeki Yaşam Vadisidir. Planlamaya göre park 6 etaptan oluşmakta ve yaklaşık $1000000 \mathrm{~m}^{2}$, dir. Yaşam Vadisi 1. Etabı tamamlanmıştır. Alan büyüklüğü $242.843 \mathrm{~m}^{2}$ dir (Şekil 4), ikincisi ise ilçenin batısında bulunan sahil şeridine tasarlanmış Piri Reis Parkıdır. Alan büyüklüğü $155.190 \mathrm{~m}^{2}$ dir (Şekil 5). Beylikdüzü ilçesine ait kent parkı niteliğindeki bu parklarının toplam alanı $398.033 \mathrm{~m}^{2}$ ve kişi başına düşen park alanı $1.34 \mathrm{~m}^{2}$ ' dir (Tablo 2).

Tablo 2. Beylikdüzü ilçesinde kent parklarının kişi başına düşen alan miktarı

\begin{tabular}{lllll}
\hline İlçe & Nüfus (Kişi) & Kent Parkı $\left(\mathbf{m}^{2}\right)$ & $\begin{array}{l}\text { Kişi başina düssen } \\
\text { kent parkı }\left(\mathbf{m}^{2}\right)\end{array}$ & $\begin{array}{l}\text { Türkiye } \\
\text { standardı }\left(\mathbf{m}^{2}\right)\end{array}$ \\
\hline Beylikdüzü & 297.420 & 398.033 & 1,34 & 3,5 \\
\hline
\end{tabular}



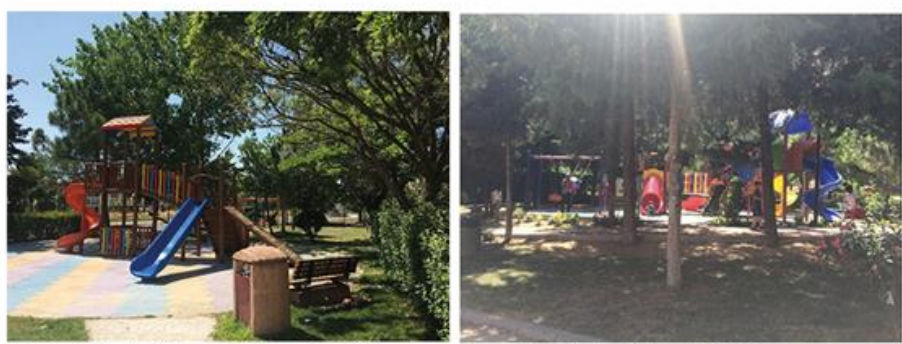

Atakent Parka (Adnan Kahveci Mah.)

Şener Şen Parkı (Barış Mah.)
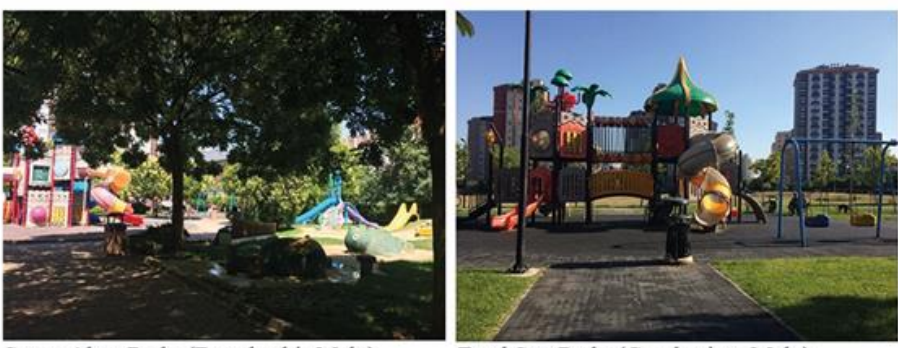

Sezen Aksu Parkı (Büyükșehir Mah.)

Fazıl Say Parkı (Cumhuriyet Mah.)
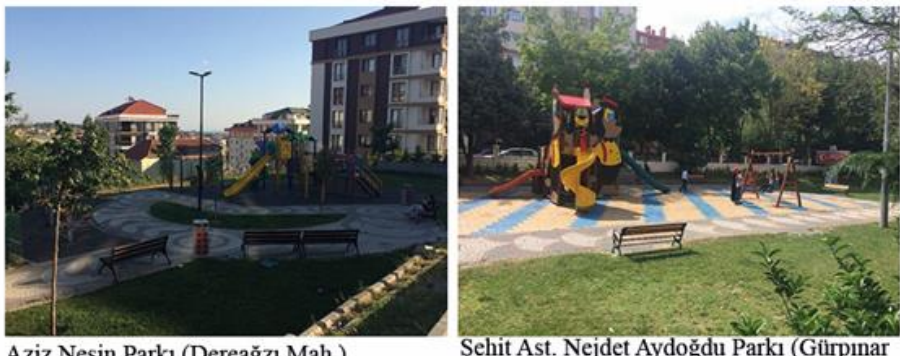

Aziz Nesin Parkı (Dereağzı Mah.) Mah.)
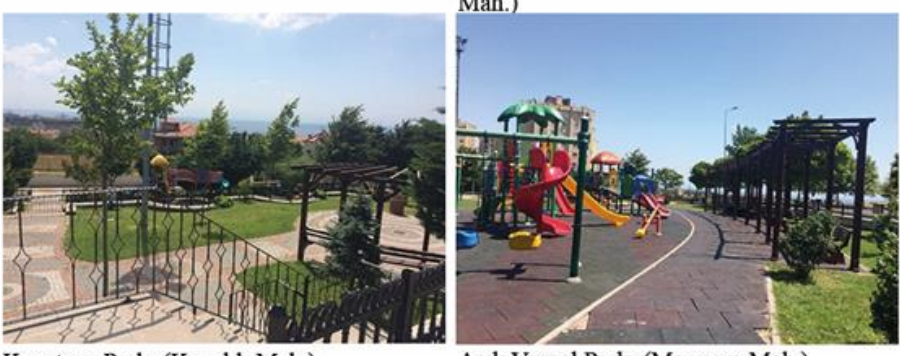

Kocatepe Parkı (Kavaklı Mah.)

Aşık Veysel Parkı (Marmara Mah.)

Şekil 3. İlçedeki bazı çocuk oyun alanlarından örnekler (Orijinal 2017)

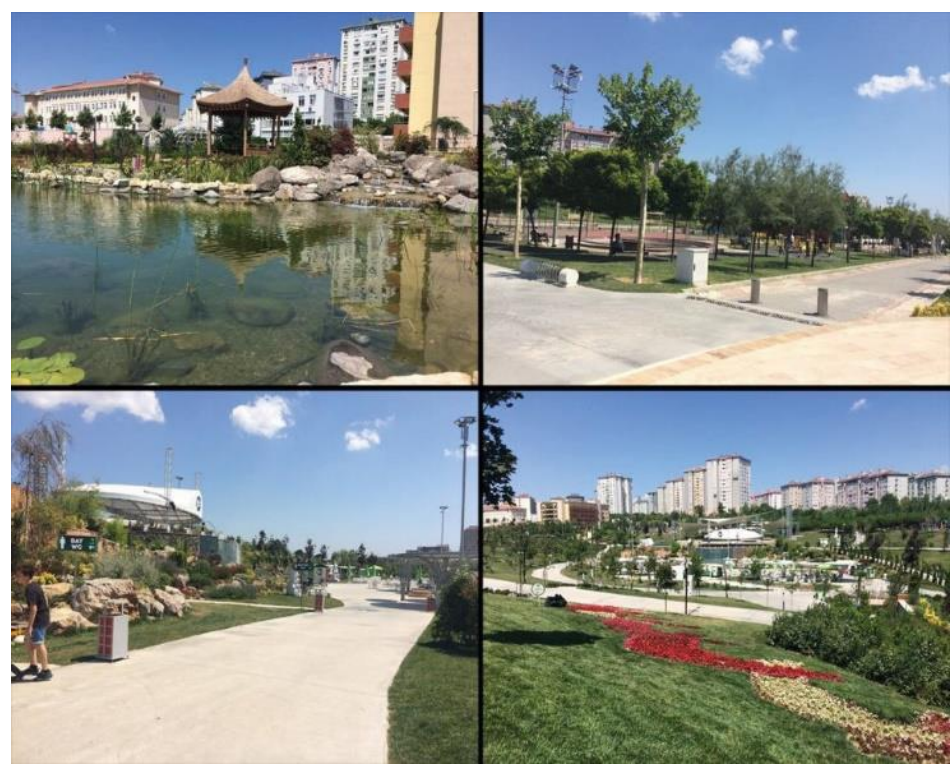

Şekil 4. Yaşam Vadisi 1. Etap (Orijinal 2017) 


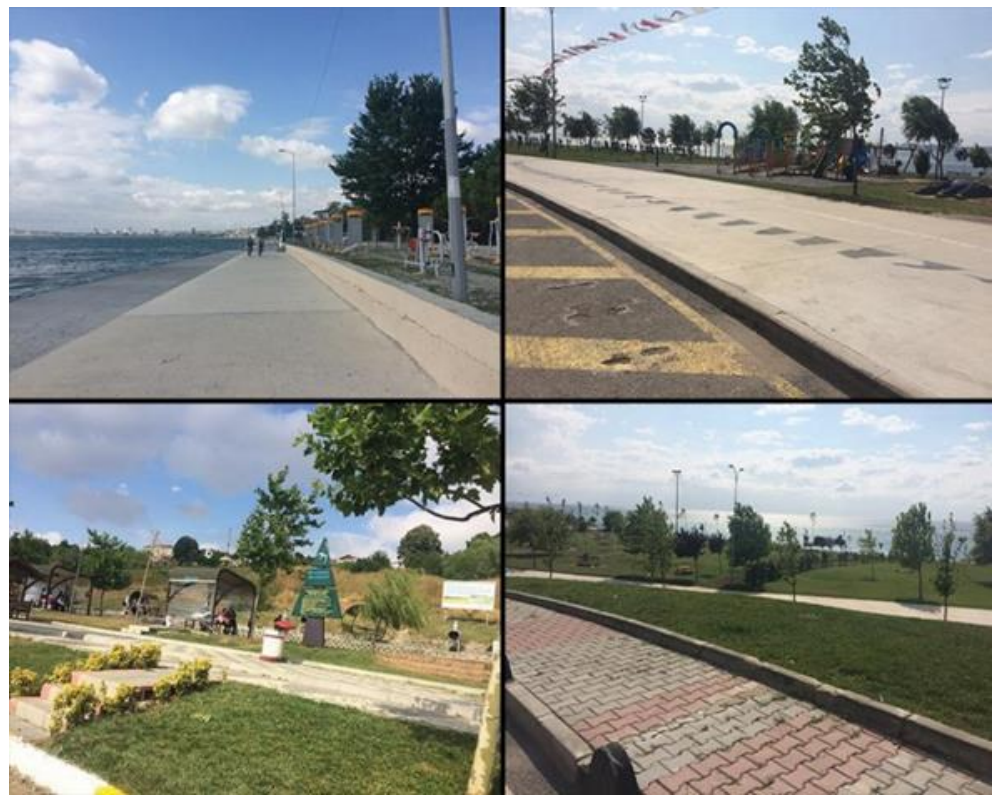

Şekil 5. Piri Reis Parkı (Orijinal 2017)

Beylikdüzü ilçesi açık spor alanları; İlçede toplam kamuya ait 85 adet açık spor alanı mevcuttur. Ayrıca ilçenin tüm mahallelerine hizmet eden 2 adet stadyum bulunmaktadır. Bu nedenle stadyum alanı mahalle spor alanlarından ayrı olarak değerlendirilmiştir. Bu doğrultuda ilçede toplam 81,325 m²'lik kamusal açık spor alanı mevcuttur. Beylikdüzü'nde kişi başına düşen toplam spor alanı 0,27 m², dir (Tablo 3) (Şekil 6).

Tablo 3. Beylikdüzü ilçesi spor alanlarının kişi başına düşen alan miktarı

\begin{tabular}{|c|c|c|c|c|}
\hline Mahalle & Nüfus (Kişi) & $\begin{array}{ll}\text { Spor } & \text { alanı } \\
\left(\mathbf{m}^{2}\right) & \end{array}$ & $\begin{array}{lr}\begin{array}{lr}\text { Kişi } & \text { başına } \\
\text { düşen } & \text { spor } \\
\text { alanı }\left(\mathrm{m}^{2}\right)\end{array}\end{array}$ & $\begin{array}{l}\text { Türkiye } \\
\text { standardı }\left(\mathbf{m}^{2}\right)\end{array}$ \\
\hline Adnan Kahveci & 80.681 & 10.132 & 0.125 & \\
\hline Barış & 51.476 & 3.140 & 0.060 & \\
\hline Büyükşehir & 20.851 & 1.365 & 0.065 & \\
\hline Cumhuriyet & 20.837 & 3.882 & 0.186 & \\
\hline Dereağzi & 10.401 & 720 & 0.069 & \\
\hline Gürpinar & 18.936 & 3.673 & 0.193 & 3 \\
\hline Kavakli & 23.596 & 4.556 & 0.193 & \\
\hline Marmara & 25.609 & 9.849 & 0.384 & \\
\hline Sahil & 4.234 & 1.711 & 0.404 & \\
\hline Yakuplu & 40.792 & 2.949 & 0.072 & \\
\hline TOPLAM & 297.420 & 41.975 & 0.14 & \\
\hline İlçe & Nüfus (Kişi) & $\begin{array}{l}\text { Stadyum } \\
\text { Alanı }\left(\mathbf{m}^{2}\right)\end{array}$ & $\begin{array}{l}\text { Kişi Başına } \\
\text { Düşsen } \\
\text { Stadyum } \\
\text { Alanı }\left(\mathbf{m}^{2}\right)\end{array}$ & $\begin{array}{l}\text { Türkiye } \\
\text { standardı } \\
\left(\mathbf{m}^{2}\right)\end{array}$ \\
\hline Beylikdüzü & 297.420 & 39.350 & $\mathbf{0 , 1 3}$ & 3 \\
\hline GENEL TOPLAM & 297.420 & 81.325 & 0,27 & \\
\hline
\end{tabular}




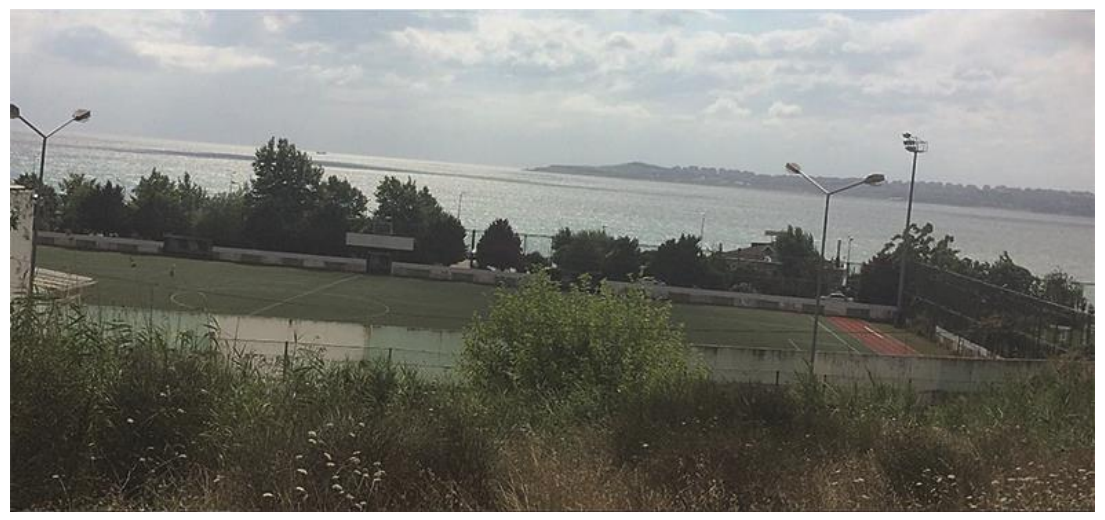

Şekil 6. Gürpınar Stadyumu (Orijinal 2017)

Beylikdüzü ilçesinde mülkiyeti kamuya ait mevcutta bulunan açık-yeşil alanlar incelenmiş, yerinde tespit edilmiş ve 1/5000 Nazım İmar Planı ile 1/1000 Uygulama İmar planıyla karşılaştııılmıştır. İlçedeki mevcut ve planlanan yeşil alanlar Şekil 7' de verilmiştir.

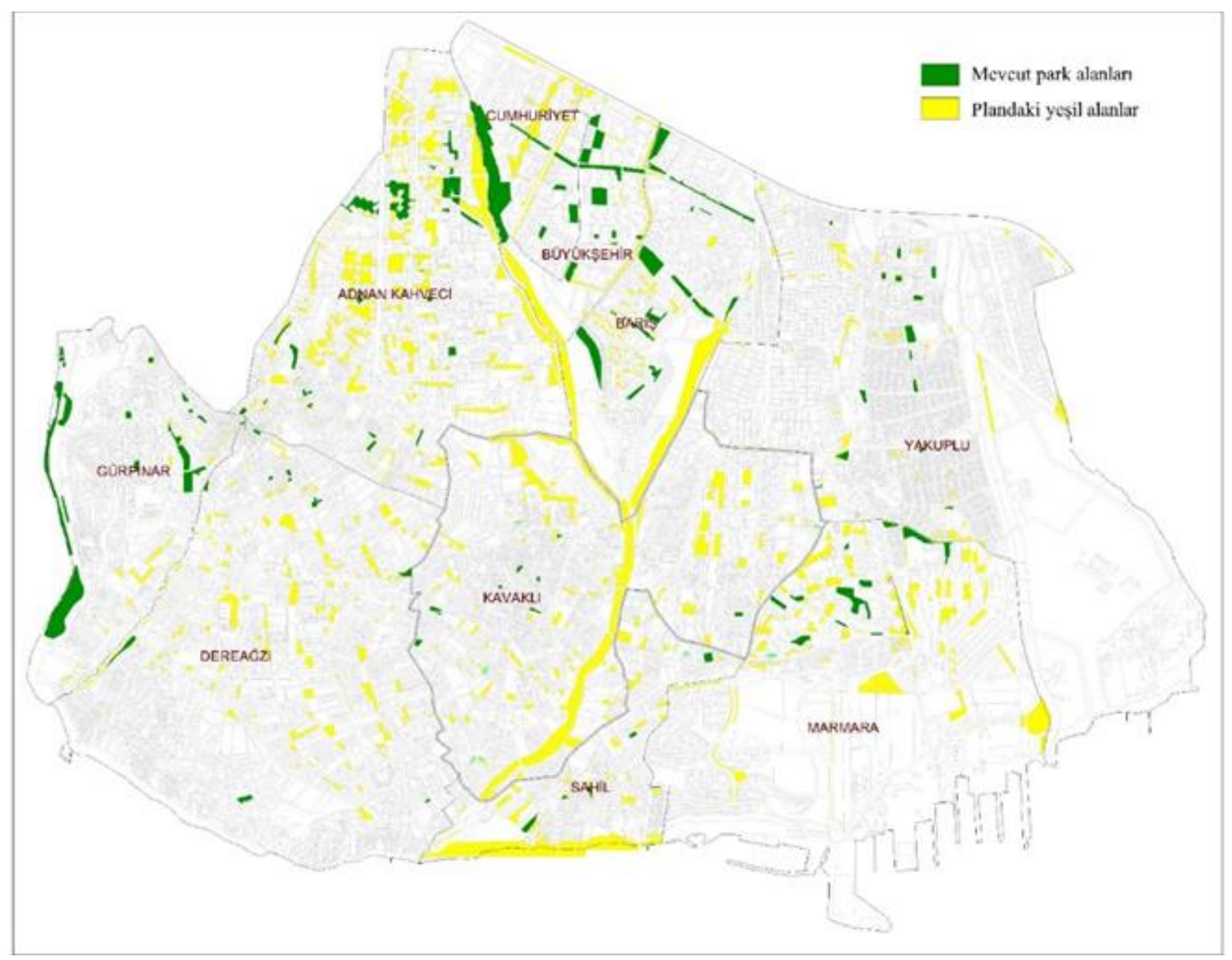

Şekil 7. İmar planı üzerindeki mevcut park alanları

Park alanlarının büyüklüğü kadar konumları da oldukça önemlidir. Açık-yeşil alanların planlama kriterleri arasında bulunan parklara ulaşılabilirlik mesafeleri park alanlarına uygun sürede ulaşımı sağlar. Şekil 8'de görüldüğü üzere Beylikdüzü ilçesi mahalle ve kent parklarının ilçeye belirli aralıklarla dağıldığı görülmektedir. Avrupa Komisyonu Kentsel Denetim raporunda yer alan mahalle parkları için 800 m ve kent parkları için 1200 
m yürüme mesafesi dikkate alınarak imar planı üzerinde analiz yapılmıştır. Dikkate alınan mesafeler doğrultusunda Dereağzı ve Kavaklı mahallelerinde yeni park alanlarına ihtiyaç olduğu görülmektedir. Bu bölgelerde yapılaşma az olduğu için yeni park alanları da mevcut değildir.

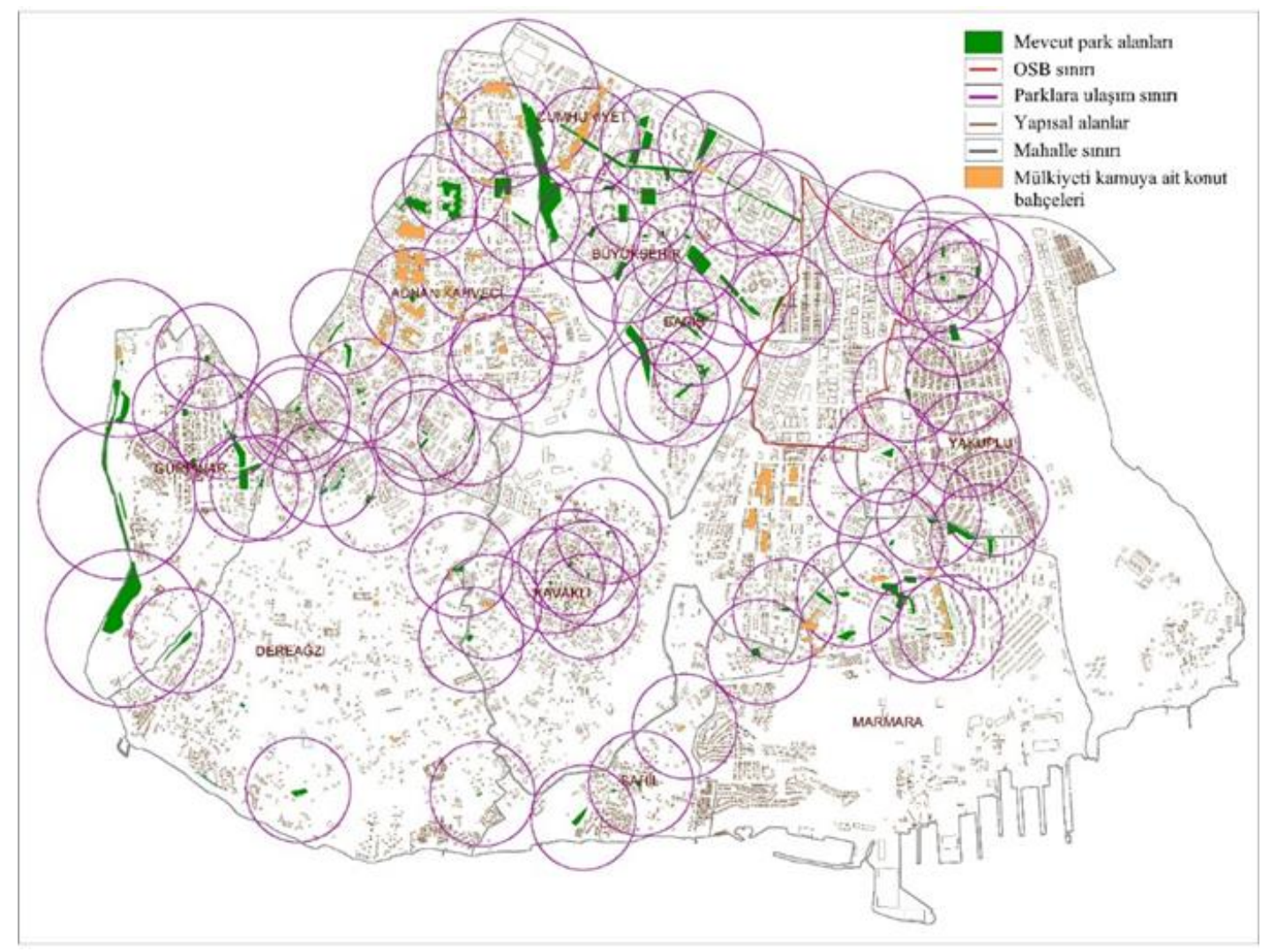

Şekil 8. Beylikdüzü mevcut park alanlarının ulaşılabilirlik durumu

Tüm bu bilgiler değerlendirildiğinde ilçe içerisinde kamuya ait mevcut aktif yeşil alan miktarı $1.015 .790 \mathrm{~m}^{2}$ ( Mahalle parkları+çocuk oyun alanları, kent parkları ve açık spor alanları) olarak hesaplanmıştır. İlçenin 2016 yılı nüfusu olan 297,420 kişi dikkate alınarak ilçede kişi başına düşen aktif-yeşil alan miktarı $3.41 \mathrm{~m}^{2}$ hesaplanmış ve bu değerin Mekansal Planlar Yapım Yönetmeliğinde belirtilen $10 \mathrm{~m}^{2}$ standardının altında olduğu görülmüşsür (Tablo 4).

Tablo 4. Beylikdüzü ilçesi kamusal aktif açık-yeşil alan durumu

\begin{tabular}{lcc}
\hline Beylikdüzü Aktif Yeşil Alanları & $\begin{array}{c}\text { Yeşil } \\
\text { Alan } \\
\text { Miktarı } \\
\left(\mathbf{m}^{\mathbf{2}}\right)\end{array}$ & $\begin{array}{c}\text { Kişi Başına Düşen Açık- } \\
\text { Yeşil Alan (m²/kişi) }\end{array}$ \\
\hline Çocuk oyun alanları + Mahalle parkları & 536,432 & \\
Kent Parkları & 398,033 & 1,80 \\
Spor Alanları & 81,325 & 1,34 \\
TOPLAM & $\mathbf{1 0 1 5 , 7 9 0}$ & 0,27 \\
\hline
\end{tabular}

İlçe içerisinde toplam $934.465 \mathrm{~m}^{2}$ park alanı bulunmaktadır. Tüm parklar içerisindeki toplam yeşil alan miktarı $454.584 \mathrm{~m}^{2}$ dir. Parkların içerdiği yeşil alan durumu değerlendiğinde park alanlarının \% \% 51 'i sert zeminden \% $\%$ ' $u$ ise yeşil alanlardan oluşmaktadır.

İlçedeki parklar donatı elemanlarının kullanımı açısından değerlendirildiğinde; \%19'da su öğesi, \%22'sinde kapalı alan, \%79'unda çocuk oyun alanı, \%61'inde fitness aletleri, \%32'sinde pergola-kamelya, \%84'ünde bank, \%81'inde çöp kutuları ve \%70'inde ise aydınlatma elemanı olduğu görülmüştür (Şekil 10). 


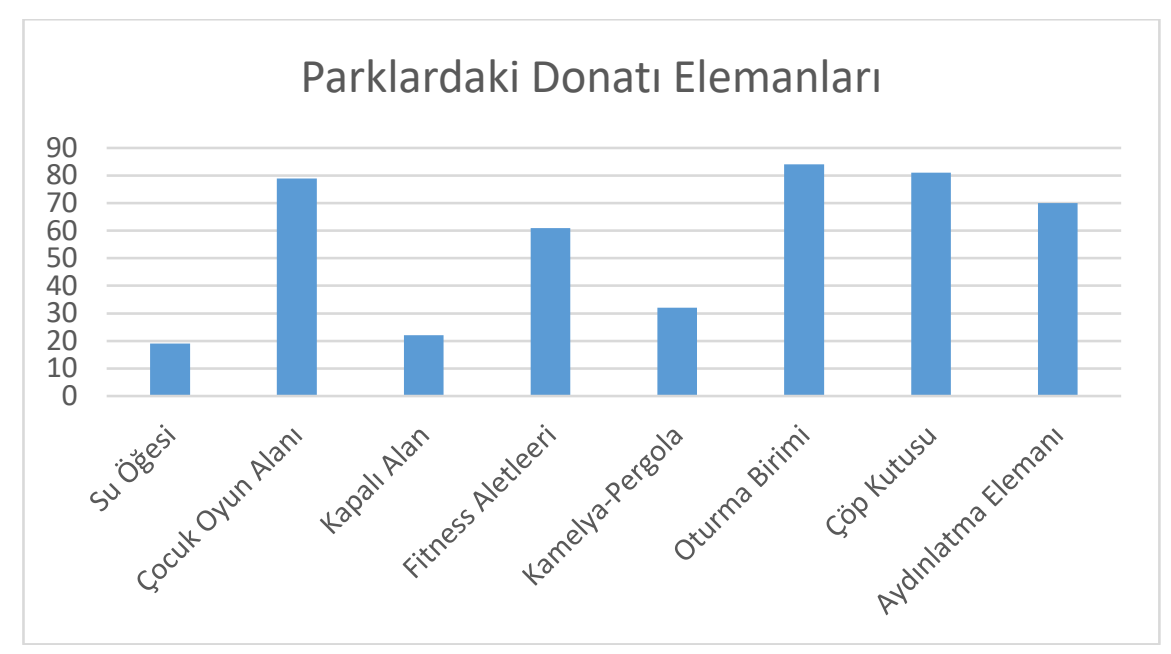

Şekil 10. Parklarda kullanılan donatı elemanları

Aktif yeşil alanlar içerisinde yer alan açık spor alanları ilçenin çeşitli yerlerine, basketbol sahaları, voleybol sahaları, futbol sahaları, tenis kortları, halı sahalar ve stadyumlar olarak dağıldığ 1 görülmektedir. İlçe genelinde toplam $81.325 \mathrm{~m}^{2}$ kamusal açık spor sahası bulunmaktadır. Bu spor alanlarının genelinin, yapılan gözlemler sonucunda iyi durumda olduğu tespit edilmiştir. İlçede 24 adet futbol sahası, 53 adet basketbol sahası, 5 adet tenis sahası ve 3 adet voleybol sahası bulunmaktadır. Bu sahalarda kullanılan zemin elemanları değerlendirildiğinde; Futbol sahalarının \%8'i çim, \%25'i kavuçuk, \%67'si ise halı saha zemininden, basketbol sahalarının \%58'i kavuçuk, \%42'si ise beton zeminden, tenis sahalarının \%100'ü beton zeminden ve voleybol sahalarının \%67'si kum, \%33’ü ise beton zeminden oluşmaktadır (Şekil 11).

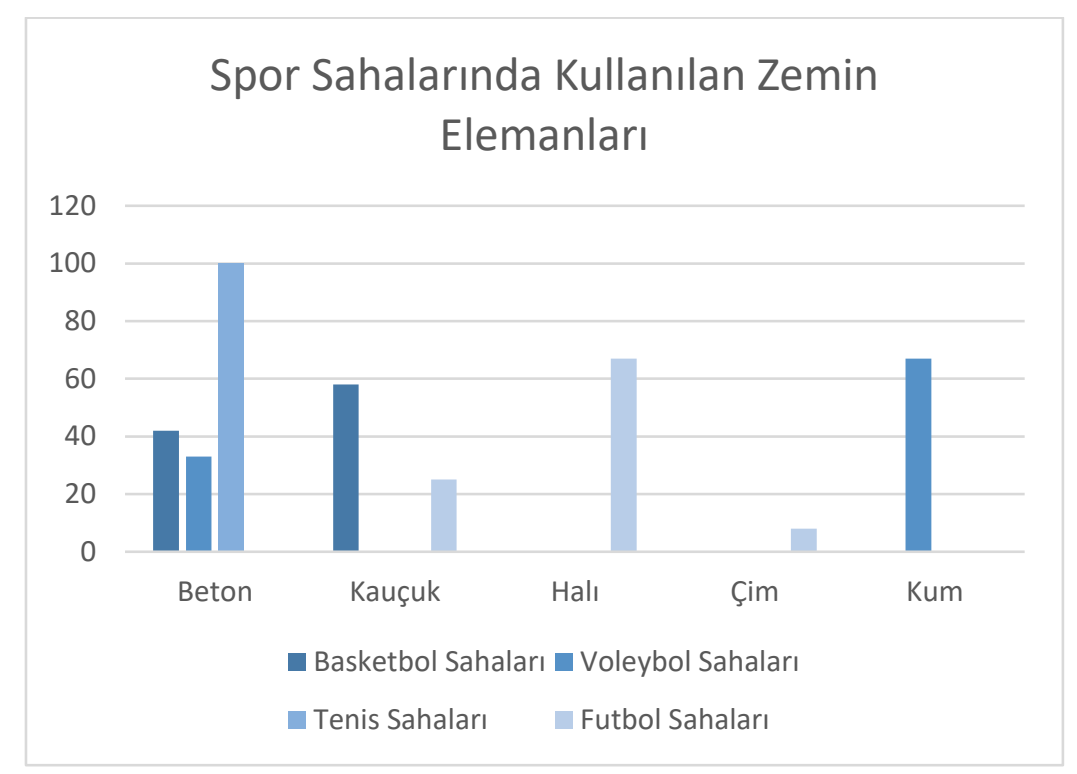

Şekil 11. Açık spor sahalarında kullanılan zemin elemanları

\section{Sonuç ve Öneriler}

Beylikdüzü, tarihi süreçte; doğal bitki örtüsünün yerini 50’li yıllarda tarım arazilerinin alması ve 80’li y1llarda bölgenin imara açılmasıyla, tarım arazilerinin yerini konut alanları almaya başlaması ile değişime uğramıştır. Günümüzde de İstanbul'un hızlı nüfus artışının ve yapılaşmanın en yoğun olduğu ilçelerinden birisidir. Bu bağlamda İlçede mevcut açık-yeşil alanların korunması ve nitelikli yeşil alan sisteminin oluşturulması önem taşımaktadır.

Açık yeşil alan miktarının belirlenmesi ile ilgili Türkiye'de pek çok çalışma bulunmaktadır (Aksoy 2001; Gül ve Küçük 2001; Ülger ve Önder 2006; Levend 2008; Atabeyoğlu ve Bulut 2012; Öztürk ve Özdemir 2013; Yücekaya 
2013; Köşe ve Kara 2021). Kişi başına düşen açık yeşil alan miktarlarının hesaplandığı bu çalışmalarda da miktarların $10 \mathrm{~m}^{2}$ standardının altında olduğu görülmüştür. Benzer bir şekilde bu çalışmada da aktif yeşil alan miktarı 3,41 $\mathrm{m}^{2}$ olarak hesaplanmıştır. Nüfus artış hızı ile yeşil alan artışı hızının aynı oranda olmadığ ilçede kişi başına düşen açık-yeşil alan miktarı $10 \mathrm{~m}^{2}$ 'lik standartın altında kalmıştır. Bu nedenle ilçede yeni parklara, açık spor sahalarına ihtiyaç duyulduğu görülmektedir.

Aksoy (2004) yılında Üsküdar ilçesinde planlana açık-yeşil alanlarının \%34 oranında uygulandığını belirlemiştir. Yapılan bu çalışmaya göre, Beylikdüzü ilçesindeki park alanlarının toplamı $934.465 \mathrm{~m}^{2}$, İmar planına göre planlanan park alanları toplamı ise $3.587,993 \mathrm{~m}^{2}$ dir. İmar planına göre hedeflenen park alanı \%26 oranında gerçekleşmiştir. Bu oranın artması için plandaki mahalle parkları ve kent parkı projelerinin bir an önce hayata geçmesi ve bunun için gerekli bütçenin ayrılması gerekmektedir.

Parklar her yaştan kullanıcılara hitap etmesinin yanı sıra güvenli ve kolayca erişilebilir olmalıdır (Giuliani et. al.,2021). Aksoy (2001) İstanbul, Özcan (2006) Kırıkkale, Boyacıgil ve Altunkasa (2009) Adana, Yenice (2012) Burdur, Yücekaya (2013) Kilis kenti için yaptıkları çalışmalarda açık yeşil alanların kent makro formunda dengeli bir dağılım göstermediğini, bu alanlara erişimde sorunlar olduğunu belirtilmişlerdir. Yapılan değerlendirmeler sonucunda Beylikdüzü ilçesinde de açık-yeşil alanların ilçe genelinde homojen bir dağılım göstermediği, özellikle Kavaklı ve Dereağzı mahallelerinde parklara erişim açısından sorunlar olduğu belirlenmiştir. İlçe içerisinde dağınık halde yer alan açık yeşil alanların bir sistem oluşturacak şekil bağlantılı hale getirilmesi kitlesel olarak arttırılması önem taşımaktadır. Son yıllarda yerel yönetimlerin yaptığı çalışmalar doğrultusunda ilçeye, büyük ölçekli parklar kazandırılmaktadır. Bunun son örneği 6 etaptan oluşan Yaşam Vadisi Projesidir. 2017 yılında tamamlanan projenin 1. Etabı ile ilçeye $242.843 \mathrm{~m}^{2}$ yeşil alan kazandırılmıştır. Alan aktif olarak ilçe halkı tarafından kullanılmaktadır. $191.760 \mathrm{~m}^{2}$ olan projenin 2. Etabı yapım çalışmaları devam etmektedir.

Bir alanın etkin kullanımı için, kullanım biçimi, yenileme ve bakım işlemleri ve yerel yönetimlerin tutumu oldukça önemlidir. Sürdürülebilir ilkeler ile tasarlanıp yönetilen açık-yeşil alanlar etkin kullanıma sahip alanlardır. Açıkyeşil alanların kontrolünün sağlanabilmesi için; alan için uygulanacak bakım yöntemleri ve teknikleri oldukça önemlidir. Amaç alana az müdahale ile mevcut yapının korunması ve geliştirilmesi olmalıdır. Yönetimlerin bakım işlemlerini yıllık bir planlama dâhilinde düzenli aralıklarla yapması gerekmektedir. Alanın güvenliği, içinde bulundurduğu hizmetler, yapılar ve alanın finansmanı yönetimler tarafından güvence altına alınmalıdır.

Açık-yeşil alanlar dinamik, canlı ve zamana bağlı değişim gösteren alanlardır. Tasarımcı uygulama esnasında ve sonrasında alanın sürekliliği için bakım ekibini bilgilendirmelidir. Yapılan uygulamaların kullanıcılar tarafından algılanıp kabul görmesi, alanın sahiplenilmesi için çevresel bilincin kullanıcılara kazandırılması gerekmektedir.

Kaliteli açık-yeşil alan uygulamaları yapılabilmesi için ihtiyaca ve parkların fonksiyonlarına göre donatı ihtiyaçları kesinlikle sağlanmalıdır. Mevcut parklarda ise eskiyen ve eksilen tüm donatı elemanları yenilenmelidir. Donatı elemanlarının işlevsel ve estetik özellikleri göz ardı edilmemelidir.

Beylikdüzü ilçesinin imajını belirleyen en önemli unsur toplu konut alanlarıdır. Bu konut alanları ilçenin kuzeyinden güneyine doğru her geçen gün büyümektedir. Mekansal planlamada ilçe genelinde özellikle imar planında yeşil alan olarak planlanan alanlar korunmalı farklı kullanımlara dönüştürülmemelidir.

\section{Bilgilendirme}

Bu çalışma, 2018 yılında Namık Kemal Üniversitesi Fen Bilimleri Enstitüsünde Peyzaj Mimarlığı Anabilim Dalı'nda tamamlanan "Beylikdüzü İlçesi Açık - Yeşil Alan Sisteminin Mevcut Durumunun Değerlendirilmesi” isimli Yüksek Lisans tezinden üretilmiştir.

\section{Kaynaklar}

1. Aksoy, Y., (2001). İstanbul Kenti Açık Yeşil Alan Durumunun İrdelenmesi, İstanbul Teknik Üniversitesi Fen Bilimleri Enstitüsü, Doktora Tezi, (Basılmamış).

2. Aksoy, Y., (2004). Üsküdar İlçesi Açık Yeşil Alan Durumunun İrdelenmesi. Ekoloji, 13:52, s: 38-44.

3. Albayrak, B., (2006). Çorum Kenti Mevcut Alan Kullanım Kararları ve Açık-yeşil Alan Verilerinin Değerlendirilmesi Üzerinde Bir Araştırma, Ankara Üniversitesi Fen Bilimleri Enstitüsü, Peyzaj Mimalığı Anabilim Dalı, Yüksek Lisans Tezi, (Basılmamış).

4. Altunkasa, F., (2004). Adana'nın Kentsel Gelişim Süreci ve Yeşil Alanlar. Adana Kent Konseyi Çevre Çalışma Grubu Bireysel Raporu, Adana, 24 s.

5. Anonim (2014). Mekansal Planlar Yönetmeliği, Resmi Gazete Sayı: 30113, 14.06.2014 Tarih. 
6. Anonim (2017a). http://www.beylikduzu.gov.tr/ilcemiz-hakkinda (25.03.2017).

7. Anonim (2017b). https://biruni.tuik.gov.tr/medas/?kn=95\&locale=tr (11.06.2017).

8. Anonim (2017c). http://www.beylikduzukentbellegi.com/Icerik/Goruntule/327 (08.04.2017).

9. Anonim (2017d) http://www.beylikduzukentbellegi.com/Icerik/Goruntule/6185 (08.04.2017).

10. Anonim (2017e) Beylikdüzü Parkları ve Açık Spor Alanları Envanterleri, Beylikdüzü Belediyesi Park ve Bahçeler Müdürlüğü, İstanbul

11. Atabeyoğlu, Ö., ve Bulut, Y., (2012). Ordu Kenti Mevcut Yeşil Alanlarının Değerlendirilmesi, Araştırma, Akademik Ziraat Dergisi, 1(2): 67-76.

12. Budak, E., (2010). Cumhuriyet Döneminde Antakya Kenti Açık ve yeşil Alan Sisteminin İrdelenmesi. Yüksek Lisans Tezi (yayımlanmamış), Mustafa Kemal Üniversitesi Fen Bilimleri Enstitüsü, Peyzaj Mimarlığı Anabilim Dalı, Hatay.

13. Boyacıgil O. ve Altunkasa, F., (2009). Adana Kuzeybatı Üst Kentsel Gelişme Alanı Örneğinde Verimli Aktif Yeşil Alan Olanaklarının Belirlenmesi. Akdeniz Üniversitesi Ziraat Fakültesi Dergisi, 22(1), 5967

14. Çetiner, A., (1990). Günümüze Kadar İstanbul' da Planlama Eylemleri ve Yarattığı Çevre Sorunları. İstanbul'un Çevre Sorunları ve Çözümleri Sempozyumu, Ekim 1990, İstanbul, s:407-410.

15. Ceylan, A., (2007). Yaşam Kalitesinin Arttırılmasında Kentsel Yeşil Alanların Önemi ve Kentsel Dönüşüm İle İlişkilendirilmesi. Yüksek Lisans Tezi (yayımlanmamış), İstanbul Teknik Üniversitesi Fen Bilimleri Enstitüsü, İstanbul.

16. Chiesura, A. (2004). The role of urban parks for the sustainable city. Landscape and Urban Planning, 68: $129-138$

17. Çinçinoğlu, A., (2001). Antakya Kenti Açık ve Yeşil Alan Sisteminin Saptanması ve Peyzaj Mimarlığı Açısından Değerlendirilmesi. Yüksek Lisans Tezi (yayımlanmamış), Mustafa Kemal Üniversitesi, Fen Bilimleri Enstitüsü, Peyzaj Mimarlığı Anabilim Dalı, Hatay.

18. Daniels, B., Zaunbrecher, B.S., Paas, B., Ottermanns, R., Ziefle, M. ve Roß-Nickoll, M. (2018). Assessment of urban green space structures and their quality from a multidimensional perspective. Science of the Total Environment, 1364-1378.

19. Değerliyurt, M., (2014). Kentlerde Mekanın Kullanımını Etkileyen Faktörler, Kent Çalışmaları 1, Detay Yayıncilik, Ankara.

20. Dil, M., (2004). İstanbul'un, Yeşil Alan Sisteminin, Planlama Kriterleri Açısından İrdelenmesi. Yüksek Lisans Tezi (yayımlanmamış), İstanbul Teknik Üniversitesi Fen Bilimleri Enstitüsü, İstanbul.

21. European Communities, (2000). The Urban Audit: Towards the benchmarking of quality of life in 58 European cities. Vol I, II and III, Office for Official Publications of the European Commnities, Luxembourg ISBN 92-828-9241-7.

22. Eren, E., (2012). Kentsel Açık Ve Yeşil Alanların Dağılımlarının Tarihi Süreç İçerisindeki Değişimi. Yüksek Lisans Tezi (yayımlanmamış), Karadeniz Teknik Üniversitesi Fen Bilimleri Enstitüsü, Peyzaj Mimarlığı Anabilim Dalı, Trabzon.

23. Garcia, D.A. (2017). Green areas management and bioengineering techniques forimproving urban ecological sustainability. Sustainable Cities and Society, 30:108 - 117. http://dx.doi.org/10.1016/j.scs.2017.01.008.

24. Giuliani, G., Petri, E., Interwies, E., Vysna, V., Guigoz, Y., Ray, N. ve Dickie, I., (2021). Modelling Accessibility to Urban Green Areas Using Open Earth Observations Data: A Novel Approach to Support the Urban SDG in Four European Cities. Remote Sens. 2021, 13, 422. https:// doi.org/10.3390/rs13030422

25. Gül, A. ve Küçük, V., (2001). Kentsel Açık - Yeşil Alanlar ve Isparta Kenti Örneğinde İrdelenmesi, Süleyman Demirel Üniversitesi Orman Fakültesi Dergisi, Süleyman Demirel Üniversitesi Orman Fakültesi, Peyzaj Mimarlığı Bölümü, Isparta.

26. Gül, A., Dinç, G., Akın, T ve Koçak, A.İ. (2020). Kentsel Açık ve Yeşil Alanların Mevcut Yasal Durumu ve Uygulamadaki Sorunlar. İdeal Kent Kentleşme ve Ekonomi Özel Sayısı, Cilt Volume 11, Y1l Year 2020-3, 1281-1312, DOI:10.31198/idealkent.650461.

27. Klompmaker, J.O., Hoek, G., Bloemsma, L.D., Gehring, U., Strak, M., Wijga, A.H., Brink, C.V.D., Brunekreef, B., Lebret, E. ve Janssen, N.A.H. (2018). Green space definition affects associations of green space with overweight and physical activity. Environmental Research, 160:531 540. http://dx.doi.org/10.1016/j.envres.2017.10.027.

28. Köşe, H. ve Kara, B. (2021). Söke (Aydın) Kenti Aktif Açık-Yeşil Alanlarının Yeterliliğinin İncelenmesi, Kent Akademisi, Volume, 14, Issue 2, Pages, 374-388.

29. Larson, L., Jennings, V., and Cloutier, S., (2016). Public Parks and Wellbeing in Urban Areas of the United States, Plos One, Ed: Christopher A. Lepczyk, PMC4824524, USA 
30. Levend, T. (2008). İstanbul İli Bayrampaşa İlçesi Açık Ve Yeşil Alanlarının Nitelik ve Nicelik Açısından İrdelenmesi. Yüksek Lisans Tezi (yayımlanmamış), Selçuk Üniversitesi Fen Bilimleri Enstitüsü, Peyzaj Mimarlığı Anabilim Dalı, Konya.

31. Melchert, L., (2005). The Dutch sustainable building policy: A model for developing countries. Building and Enviroment, 42 (2), 893-901.

32. Önder, S. (1997). Konya Kenti Açık ve Yeşil Alan Sisteminin Saptanması Üzerinde Bir Araştırma. Doktora Tezi (yayınlanmamış), Ankara Üniversitesi Fen Bilimleri Enstitüsü Peyzaj Mimarlığı Anabilim Dalı, Ankara.

33. Öztürk, S. ve Özdemir, Z. (2013). Kentsel Açık ve Yeşil Alanların Yaşam Kalitesine Etkisi “Kastamonu Örneği”. Kastamonu Üniversitesi, Orman Fakültesi Dergisi, 2013, 13 (1): 109-116

34. Özcan, K., (2006). Sürdürülebilir Kentsel Gelişmede Açık-Yeşil Alanların Rolü "Kırıkkale, Türkiye Örneği. Ekoloji, 15:60, s: 37-45.

35. Polat, A. ve Önder, S., (2012). Kentsel Açık-Yeşil Alanların Kent Yaşamındaki Yeri ve Önemi, Kentsel Peyzaj Alanlarının Oluşumu ve Bakım Esasları Semineri, Selçuk Üniversitesi Ziraat Fakültesi Peyzaj Mimarlığı Bölümü, Konya.

36. Sağlam, S., (2006). Türkiye'de İç Göç Olgusu ve Kentleşme, Hacettepe Üniversitesi Türkiyat Araştırmaları Enstitüsü, Hacettepe Üniversitesi, Ankara.

37. Ülger, F., ve Önder, S., (2006). Kayseri Kenti Açık-Yeşil Alanlarının Nitelik Ve Nicelik Açısından İrdelenmesi, Selçuk Üniversitesi Ziraat Fakültesi Dergisi, 20 (38): (2006) 108-118, Konya.

38. Yenice, M.S., (2012). Kentsel yeşil alanlar için mekânsal yeterlilik ve erişebilirlik analizi; Burdur Örneği, Türkiye. SDÜ Orman Fakültesi Dergisi / SDU Faculty of Forestry Journal 2012, 13: 41-47

39. Yıldızcı, A.C., (1987). Kentsel Yeşil Alanlar Ders Notları, İstanbul.

40. Yücekaya, M. (2013). Kilis'te açık yeşil alanlar ve park nitelikleri. Yüksek Lisans Tezi (yayımlanmamış), Erciyes Üniversitesi Fen Bilimler Enstitüsü, Peyzaj Mimarlığı Anabilim Dalı, Kayseri, 152s.

41. Zhang, Y., Dijk, T., Tang, J., and Berg, A., (2015). Green Space Attachment and Health: A Comparative Study in Two Urban Neighborhoods, International Journal of Environmental Research and Public Health, US National Library of Medicine National Institutes of Health, Ed: Paul B. Tchounwou, PMC4661652, Netherlands. 